\title{
$>$ Approaching Fäerie: a study of J. R. R. Tolkien's on fairy-stories
}

\author{
> Abordando Fäerie: um estudo sobre histórias de fadas de J. R. R. Tolkien
}

\begin{abstract}
por Fabian Quevedo da Rocha
É mestrando em Letras pelo Instituto de Letras, Programa de Pós-Graduação em Letras, da Universidade Federal do Rio Grande do Sul (UFRGS). E-mail: fabianway07@gmail.com. ORCID: 0000-0003-0497-8340.
\end{abstract}

\begin{abstract}
This article discusses J.R.R. Tolkien's understanding of fantasy as a literary genre in light of his essay On Fairy Stories. It addresses key concepts of the essay that are of great importance for a broader understanding of the author's creative process and his views on the importance of fantasy stories for society. Among the concepts discussed in this analysis are Tolkien's ideas of sub-creation, secondary world, inner consistency of reality, as well as his views on Recovery, Escape, and Consolation, which he believed to be the main functions of fantasy. Finally, the concept of Fäerie, which is probably the most important term in the author's lexicon and key to his theory and practice, is also discussed in this work.
\end{abstract}

Keywords: Fäerie. Fantasy Literature. J. R. R. Tolkien. On Fairy Stories.

\section{Resumo}

Este artigo discute a compreensão de Tolkien a respeito do gênero literário fantasia, como proposto em seu ensaio Sobre Histórias de Fadas. Abordam-se conceitos chave do ensaio que são de suma importância para uma compreensão mais ampla do processo criativo do autor e também de sua visão a respeito da importância de histórias de fantasia para a sociedade. Entre os conceitos discutidos neste trabalho estão as ideias de Tolkien sobre subcriação, mundo secundário, consistência interna de realidade, assim como suas definições de Cura, Escape, e Consolo, que o autor acreditava serem as principais funções da fantasia. Discute-se, também, o conceito de Fäerie, que é provavelmente o termo mais importante do léxico do autor e que é fundamental para sua teoria e prática.

Palavras-chave: Fäerie. J. R. R. Tolkein. Literatura de Fantasia. Sobre Histórias de Fadas. 


\section{Approaching fäerie}

In an attempt to discuss the significance of Tolkien's On Fairy Stories to his own creative process, I believe it is of considerable importance to start by looking at the title of the essay, which, to a certain extent, casts some light on the author's idea of fairy stories. One of the three questions the writer endeavors to address in his essay, even if partially, concerns the definition of fairy stories. In doing so, one of the first conclusions he draws is that, curiously enough, this kind of story is not particularly about fairies, but about what the author calls Fäerie, which is, as he argues, the realm in which fairies have their being. Fäerie, as Tolkien describes, is a perilous land filled with pitfalls and dungeons as well as "[...] dwarfs, witches, trolls, giants, or dragons: it holds the seas, the sun, the moon, the sky; and the earth, and all things that are in it: tree and bird, water and stone, wine and bread, and ourselves, mortal men, when we are enchanted"1. In addition to that, when addressing the quality of fairy stories, the author claims that most of the good stories of this kind involve the aventures of men in the perilous realm of Fäerie. It is important to draw attention to the fact that instead of using the English word adventures, Tolkien opted for using the French term aventure, which, as Flieger points out, is much more comprehensive than adventure: the word aventure is similar in sound and spelling to the Old French term avant, which means "forward". Therefore, it may be argued that aventure connotes "moving into danger, the perilous unknown, the extraordinary, and ultimately the supernatural; that is to say, the secondary or otherworld called by medieval poets la forêt des aventures, and by Tolkien, the perilous realm of Fäerie"2.

By taking the notion above into consideration, it is possible to argue that (1) fairy stories are stories that take place in the realm of Fäerie, and that (2) such realm is home to the things that are regarded as fantastic and extraordinary in our world. In other words, fairy stories are, as Brian Attebery and John Clute

\footnotetext{
${ }^{1}$ J. R. R. Tolkien, Tree and Leaf, 2001, p. 9.

${ }^{2}$ Verlyn Flieger, There Would Always be a Fairy Tale, 2017, p. 34.
} 
point out, fantasy stories whereas Fäerie, on the other hand, is the realm in which fantastic events are made possible, it is the realm of fantasy. ${ }^{3}$ The way I see it, fantasy is concerned with (but not limited to) possibility. This is not to say, of course, that fantasy is about things that are possible in the real world. Contrary to that, it is about the power of giving to imagination and imagined things what is called Secondary Belief, "(...) a belief that accepts the inner reality of the story and believes in its 'truth' as long as the reader's mind is there within that story's bounds"4. However, great skills are needed to induce such kind of belief; as Tolkien points out, it requires that story-makers prove themselves to be successful sub-creators. This means that they must create a secondary world, the world their stories take place, in which the readers' minds can enter. ${ }^{5}$ In such secondary worlds, the stories and events narrated, unlikely as they may be, are regarded as true, mostly because they are in accordance with the laws of such worlds. Tolkien names this quality the "inner consistency of reality" and in view of its relationship with Fantasy, he argues that:

\begin{abstract}
Fantasy has also an essential drawback: it is difficult to achieve. Fantasy may be, as I think, not less but more sub-creative; but at any rate it is found in practice that "the inner consistency of reality" is more difficult to produce, the more unlike are the images and the rearrangements of primary material to the actual arrangements of the Primary World. [...] Anyone inheriting the fantastic device of human language can say the green sun. Many can then imagine or picture it. But that is not enoughthough it may already be a more potent thing than many a "thumbnail sketch" or "transcript of life" that receives literary praise. To make a Secondary World inside which the green sun will be credible, commanding Secondary Belief, will probably require labour and thought, and will certainly demand a special skill, a kind of elvish craft. Few attempt such difficult tasks. But when they are attempted and in any degree accomplished then we have a rare achievement of Art: indeed narrative art, story-making in its primary and most potent mode. ${ }^{6}$
\end{abstract}

Such rare achievement mentioned by Tolkien bears a relationship to a quality to which fantasy aspires and which he refers to as enchantment. Therefore, it may be argued that fantasy allows that imagined things are given

\footnotetext{
${ }^{3}$ Brian Attebery, Stories about stories, 2014, p. 7; John Clute, The Encyclopedia of Fantasy, 1996, p. 345.

${ }^{4}$ Jay Ruud, Critical Companion to J. R. R. Tolkien, 2011, p. 344.

${ }^{5}$ J. R. R. Tolkien, Tree and Leaf, 2001, p. 37.

6 J. R. R. Tolkien, Tree and Leaf, 2001, p. 48-49. Emphasis in the original.
} 
secondary belief by an author's creation of a secondary world. Such belief, however, depends on the author's ability to produce enchantment, which is intrinsically connected to the writer's skill of giving to its secondary world an inner consistency of reality. That is why Tolkien argues that we, as mortal human beings, are only present in the Fäerie realm if we are enchanted. Our immersion into such realm is associated with the power of fantasy narratives of producing enchantment, the doors to that kingdom. Such idea is connected to the derivation of the word fäerie itself, which, as Flieger argues, comes from the Old French fae or fée (fairy) joined by the suffix ery/erie: when one of these suffixes is added to the root noun fae, the resulting abstract noun denotes process or state, so we have fay-ery, which means both the practice of enchantment and the state of being enchanted. ${ }^{7}$

Tolkien believed that fantasy was a natural human activity, which has to do, to a large extent, with the idea that it offers us a kind of consolation and satisfaction to some of our old ambitions and desires, such as some people's wishes to visit the deep seas, to fly like a bird, to converse with other living things, or even what Tolkien called our oldest and deepest desire: the Escape from Death. Such wishes and desires may be accomplished through fantasy stories mostly because of their advantage of arresting strangeness. Tolkien believed that fantasy narratives had, to a considerable extent, an advantage over more realistic texts because of their capacity of, as Flieger suggests, at the same time, alienating and capturing the attention of readers. ${ }^{8}$ Such capacity is intrinsically connected with the potential of fantasy for presenting things from a perspective that is totally different from our world or which do not exist in it. This potential makes them credible and consistent in a secondary world; in this sense, writers may, as Tolkien suggests, take green from grass and blue from the sky and make new form:

We may put a deadly green upon a man's face and produce a horror; we may make the rare and terrible blue moon to shine; or we may cause

\footnotetext{
${ }^{7}$ Verlyn Flieger, There Would Always be a Fairy Tale, 2017, p. 34.

${ }^{8}$ Ibidem, p. 40.
} 
woods to spring with silver leaves and rams to wear fleeces of gold, and put hot fire into the belly of the cold worm. But in such "fantasy," as it is called, new form is made; Faerie begins; Man becomes a sub-creator?.

When a writer places these imagined things, which are unconceivable in the real world, in the realm of Fäerie, they are, somehow, making them possible; such power is, as Tolkien points out, "[a]n essential power of Faerie (...) the power of making immediately effective by the will the visions of 'fantasy"'10. By making these imagined things possible in a secondary world, writers are satisfying another desire that may be satisfied through fantasy: the desire for sub-creation. Tolkien was a Roman catholic, which means that he believed that the world and all things in it were made by a Creator (i.e.: God) and that, therefore, this God was the only entity capable of creating new forms and things. Human beings, in this sense, were only capable of a lesser kind of creation, namely sub-creation. Tolkien describes this kind of creation as the process by which an artist creates an internally consistent secondary world. In addition to that, the author believed that through such process human beings could, somehow, emulate the original Creator and restore His image, which is where we, human beings, were created. Tolkien expressed these ideas not only in his essay On Fairy Stories, but also on his poem Mythopoeia. The poem was written in response to his contemporary and friend C. S. Lewis, who had claimed that myths were lies "breathed through silver"11. An excerpt of such poem that summarizes Tolkien's views on sub-creation is presented below:

The heart of man is not compound of lies,/ but draws some wisdom from the only Wise,/ and still recalls him. Though now long estranged,/ Man is not wholly lost nor wholly changed./ Disgraced he may be, yet is not dethroned,/ and keeps the rags of lordship once he owned,/ his worlddominion by creative act:/ not his to worship the great Artefact,/ man, sub-creator, the refracted light/ through whom is splintered from a single White/ to many hues, and endlessly combined/in living shapes that move from mind to mind./ Though all the crannies of the world we filled/ with Elves and Goblins, though we dared to build/ Gods and their houses out of dark and light,/ and sow the seed of dragons, 'twas our right/ (used or

\footnotetext{
9 J. R. R. Tolkien, Tree and Leaf, 2001, p. 22 a 23.

${ }^{10}$ Ibidem, p. 23.

${ }^{11}$ Ibidem, p. 85
} 
misused). That right has not decayed./ We make still by the law in which we're made ${ }^{12}$.

Fantasy, then, is a natural human activity. It has the advantage of arresting strangeness, while it also satisfies the human desire for sub-creation. Despite the feelings of unreality that the world "fantasy" may evoke and the idea that one of its qualities is that of arresting strangeness, Tolkien claims that fantasy narratives are largely made of the real world. However, if the artist proves to be a good craftsman, they will be able to (re)shape the elements that are present in that world so that they could appear in the secondary world in a greater light:

[b]y the forging of Gram cold iron was revealed; by the making of Pegasus horses were ennobled; in the Trees of the Sun and Moon root and stock, flower and fruit are manifested in glory. And actually fairy-stories deal largely, or (the better ones) mainly, with simple or fundamental things, untouched by Fantasy, but these simplicities are made all the more luminous by their setting ${ }^{13}$.

A further quality of fantasy that Tolkien underscores is its capacity of helping us see things more clearly. This capacity goes hand in hand with part of the solace that the author believed fantasy narratives could offer: Recovery and Escape. Because these aspects will be dealt with later in this paper, we will make only a few comments about them. Both these qualities may be associated with what Tolkien called the faces of fantasy stories, which are the Mystical towards the Supernatural, the Magical towards Nature, and the Mirror of scorn and pity towards Man. The author claims that while the essential face of Fäerie is the Magical, the other two may also appear in several degrees according to the storyteller's choice. One of the characteristics of the Magical face, as Tolkien points out, is its ability of working as a Mirour de l'Omme, to use the author's own words. By using this mirror, readers may see themselves reflected on the characters in the fantasy narratives and, therefore, see aspects of themselves that they had forgotten or that they had not been aware of. In this sense, through the Magical face of Fäerie, readers may (re)gain a clearer view of reality, which

\footnotetext{
${ }^{12}$ Ibidem, p. 87.

${ }^{13}$ Ibidem, p. 59.
} 
has to do with the Recovery Tolkien believed fantasy stories offered. As for Escape, it is important to note that in Tolkien's view, the term implies distance, rather than denial: fantasy narratives allow that we see not only beyond ourselves, but also beyond the situation in which we find ourselves. Like Recovery, which helps us see more clearly, Escape allows us to see further beyond and, therefore, see perspective and hope where once we thought there was only chaos and defeat. Flieger aptly summarizes Tolkien's arguments concerning the benefits of fantasy stories and the view of critics towards them by calling attention to two points Tolkien makes in his essay On Fairy Stories:

That so significant a branch of modern fiction as fantasy should be so misconstrued says more about the naysayers than about the works themselves, whose visions of alternative reality (...) have been and still are read by adults and children alike. Although "On Fairy-stories" anticipated Wilson and Greer by several decades, Tolkien's arguments show that he was well aware of the elitist intellectual high ground claimed by both. "On Fairy-stories" directly confronts such disdain with such arguments: first pointing out that the distinction between those who appreciate imaginative literature and those who do not is more a difference of taste than of age (...), and second refuting the equally unexamined assumption that escape implies denial rather than distance and instead asserting that the latter can offer perspective and foster new perception. Far from avoiding reality, Tolkien declares, fantasy works to let us see it more clearly ${ }^{14}$.

In metaphorical terms, fantasy narratives aid writers to convey their messages more powerfully and readers to internalize them more easily. In other words, as Attebery believes, fantasy has the potential of creating metaphors that communicate truths that the conscious mind either cannot comprehend or fears to face. ${ }^{15}$ In addition to that, Tolkien argues that fantasy narratives have an essential role to play in society, mainly during times of great distress. Such role, he believes, aims to provide four things: Fantasy, Escape, Consolation, and Recovery. ${ }^{16}$ Largely because of that, the author claims that this kind of narrative

\footnotetext{
${ }^{14}$ Verlyn Flieger, There Would Always be a Fairy Tale, 2017, p. 33.

${ }^{15}$ Brian Attebery, Stories about stories, 2014, p. 9.

${ }^{16}$ The possibility of Escape, Recovery and Consolation in a narrative, Tolkien believes, is conditioned to the existence of Fantasy. For this reason, the writer dedicates an exclusive section to the discussion of the latter, while the first are discussed jointly.
} 
is a higher form of art, the most nearly pure form, to use his own words; thus, when such art is achieved, it is, he believes, the most powerful one.

\section{Recovery, Escape and Consolation}

In this section, we will be looking at the solace offered by fantasy narratives, as brought forth by Tolkien: Escape, Recovery, and Consolation. However, before addressing these three items, which Tolkien regarded as the central functions of fantasy stories, I would like to go back to my claim that fantasy relates to possibility and contrast it with Tolkien's views of fantasy stories and desirability.

In the essay On Fairy Stories, Tolkien argues that fantasy stories were primarily concerned with desirability, rather than with possibility. ${ }^{17}$ Before such claim, it seems timely to discuss my own ideas of possibility as well as Tolkien's. The author's point is strongly connected with Andrew Lang's claim that the great question children ask when they read a fantasy story is "is it true?" ${ }^{18}$. Tolkien, who had read Lang's Fairy Books as a child and as an adult, challenged the writer's proposition as he stated that the fact that a story might or might not happen in the real world is not a condition for a reader to enjoy it:

I had no special "wish to believe." I wanted to know. Belief depended on the way in which stories were presented to me, by older people, or by the authors, or on the inherent tone and quality of the tale. But at no time can I remember that the enjoyment of a story was dependent on belief that such things could happen, or had happened, in "real life ${ }^{19 "}$.

It may be argued that Tolkien's idea of possibility was intrinsically associated with the idea that the events in fantasy stories could happen in real life. My idea of possibility, on the other hand, is about the power fantasy has in

\footnotetext{
17 J. R. R. Tolkien, Tree and Leaf, 2001, p. 41.

${ }^{18} \mathrm{~A}$ Scottish evolutionary anthropologist, folklorist and writer of the nineteenth century known for the works Custom and Myth (1884), Myth, Ritual and Religion (1887) as well as the 12 colored Fairy Books (1889-1910).

19 J. R. R. Tolkien, Tree and Leaf, 2001, p. 40.
} 
giving to imagined things a sense of reality through the creation of an internally consistent secondary world. The way I see it, such idea seems to relate to Tolkien's concept of desirability. In his view, it is connected with the power of fantasy stories in, at the same time, awakening and satisfying some of the human beings' desires, such as the ones mentioned in the previous section (i.e.: the desire of conversing with other living things) as well as the desire for a glimpse of "Other-worlds" which was, according to the writer, at the heart of the desire of Fäerie. Tolkien, as a child (and probably as an adult, too) did not wish or long to see dragons in real life, nor did he want them "(...) intruding into [his] relatively safe world, in which it was, for instance, possible to read stories in peace of mind, free from fear"20. However, the author felt that the secondary worlds in which dragons were made possible, even though they were full of peril, were much richer and more beautiful, and so, awoke a desire for the glimpsing of such worlds. In other words, "[t]he dweller in the quiet and fertile plains may hear of the tormented hills and the unharvested sea and long for them in his heart. For the heart is hard though the body be soft" ${ }^{21}$.

Having addressed the different meanings of the term "possibility", I would like to move on to the main topic of this section: the solace that fantasy and fantasy narratives offer. Tolkien spends around one third of his On Fairy Stories discussing what he calls the values and functions of fantasy stories, which he argues to be the most important consideration regarding this kind of narrative. ${ }^{22}$ The author concludes, then, that on top of all the richness these stories may offer, there are three central elements that should be carefully considered: Escape, Recovery, and Consolation. The reasons why the author considered these three functions are worth considering.

\footnotetext{
${ }^{20}$ Ibidem, p. 41 a 42.

${ }^{21}$ Ibidem, p. 42.

${ }^{22}$ In the beginning of On Fairy Stories, Tolkien states that throughout the essay he will address three questions that he believes that anyone who ventures to talk about fantasy stories should attempt to answer, namely (1) what are fantasy stories?; (2) what is their origin?; and (3) what is their function? Towards the end of the essay, when he starts addressing the third question, he points out that it is the most important of the three.
} 
Tolkien was a war veteran and, at the time he wrote the essay On Fairy Stories, he had fought in one of the bloodiest battles of WWI - Battle of the Somme - and he lived to see the devastating consequences of such conflicts to both humanity and the natural world. In the pre-, inter-, and post- war periods, the writer saw the destruction of much of what he loved and cherished: not only was the natural world immeasurably stained and harmed, but the war also took the lives of two of Tolkien's best friends, Rob Gilson and G. B. Smith, who were both members of the T. C., B. S., the literary group Tolkien formed in his formative years. Considering the increasing chaos and fragmentation that culminated in the outbreak of the War, it is understandable that the author decided to turn to fantasy narratives, not only as a reader, but also, to a larger extent, as a writer, as a means to find some comfort and reassurance. In a 1944 letter, written as a response to his son, Christopher Tolkien, who was working on a pilot training program in South Africa during WWII, Tolkien somehow explains the reasons behind his decision to resort to fantasy writing in the face of the dark times he was living through:

I think if you could begin to write (...) you would find it a great relief. I sense amongst all your pains (some merely physical) the desire to express your feeling about good, evil, fair, foul in some way: to rationalize it, and prevent it just festering. In my case it generated Morgoth and the History of the Gnomes ${ }^{23}$.

Tolkien advised his son to do exactly what he had done during WWI: write as a means not only to regain perspective amidst the chaos he found himself in, but also to keep himself from becoming alienated by it. As Flieger points out,

[...] the Silmarillion and its offshoot, The Lord of the Rings, do indeed express his feeling about some very big issues of "good and evil, fair and foul," and his writing probably did much to prevent them festering. Among other things, Tolkien's war experience helped to sharpen his developing interest in what might seem the opposite of the gritty world of war, the world of imagination ${ }^{24}$.

\footnotetext{
${ }^{23}$ J. R. R. Tolkien, The Letters of J. R. R. Tolkien, 2000, p. 78.

${ }^{24}$ Verlyn Flieger, There Would Always be a Fairy Tale, 2017, p. 49.
} 
Therefore, Tolkien decided to use the world of imagination, the world of fantasy, as a road to reaching a clearer understanding of the ongoing events of the $20^{\text {th }}$ century. The fact that Tolkien uses the word "rationalize" in his letter, makes it sound quite unusual since when taking its meaning literally, it means "to bring into accord with reason or cause something to seem reasonable". Fantasy, the mode chosen by Tolkien to convey his ideas, is seldom associated with rationality. However, the author believed that fantasy is largely comprised of the real world. On top of that, if we look through the things that are present, similar, or even different from the ones in the primary world, in a secondary world, we can get a clearer view of them as "we are (or were) meant to see them - as things apart from ourselves"25. Such claims lead to the first function of fantasy stories as suggested by the author: Recovery.

One of the many consequences of WWI was the strong impact it had on people's ability to form connections. In other words, the devastation resulting from such conflict frequently alienated people and made them turn inwards. Such a state of things needed a kind of renovation other than the kind of renovation proposed by science or the industry, but a form of renovation which Tolkien believed was proposed by fantasy stories: the world needed Recovery. The Recovery proposed by fantasy narratives, the author argued, included both a return and renovation of health, as well as a (re)gaining of a clear view. "We should look at green again, and be startled anew (but not blinded) by blue and yellow and red. We should meet the centaur and the dragon, and then perhaps suddenly behold, like the ancient shepherds, sheep, and dogs, and horses - and wolves" 26 . By seeing how things are organized in a secondary world, how people relate to one another and to nature in that universe, one is prompted to realize how these things are in the real world and, then, maybe, return to a prior, healthier, state.

\footnotetext{
25 J. R. R. Tolkien, Tree and Leaf, 2001, p. 58.

${ }^{26}$ Ibidem, p. 57.
} 
Martha C. Sammons argues that secondary worlds may work as mirrors or metaphors for our own. Therefore, things that happen in a fantasy universe can be often applied in the primary world. The scholar believes that by placing things in a different setting, secondary worlds help us see the primary world in a different perspective. "By showing us things in a different way, the other world sheds light upon our world and helps us return to it with renewed vision"27. This is very much the Recovery brought forth by fantasy narratives. However, if on the one hand Recovery is concerned with regaining a clearer view of things, Escape, on the other, is strongly connected with, but not limited to, reaction.

Tolkien starts his considerations about Escape by sharing his understanding of the term which differs from the one of the literary critics of his time: such critics, the author argues, frequently associated fantasy narratives with escapism, which, to a considerable extent, implies, on one hand, refusal to recognize certain things, such as death and sorrow, and, on the other, an escape from one's duties and responsibilities. Tolkien, in spite of that, viewed the Escape fantasy narratives propose as a form of longing for change. To illustrate his claims concerning escape and escapism, Tolkien compares the first with the Escape of the Prisoner and the latter with the Flight of the Deserter. ${ }^{28}$ For the writer, a person who is imprisoned should neither be scorned for trying to get out and go home, nor for thinking and talking about things other than jailers and prison-walls. Non conforming with the state of things and the desire for change, as the author argues, does not make the world outside the prison less real. Likewise, someone who finds themselves in a state of things that is not favorable or desirable, should not be blamed for trying to make things better nor for reading narratives that prompt readers to action by sending messages of hope and encouragement and which could demonstrate that things may change for the better even in the face of great adversity. In this sense, the Escape fantasy narratives offer provides an escape from the ugliness of the dark days and times

\footnotetext{
${ }^{27}$ Martha C. Sammons, War of the Fantasy Worlds: C. S. Lewis and J. R. R. Tolkien on art and imagination, 2010, p. 166.

${ }^{28}$ J. R. R. Tolkien, Tree and Leaf, 2001, p. 63.
} 
in which one may find themselves. As Tolkien proposes, the $20^{\text {th }}$ century was an age of

[...] "improved means to deteriorated ends". It is part of the essential malady of such days- producing the desire to escape, not indeed from life, but from our present time and self-made misery- that we are acutely conscious both of the ugliness of our works, and of their evil. [...] But there are also other and more profound "escapisms" that have always appeared in fairytale and legend. There are other things more grim and terrible to fly from than the noise, stench, ruthlessness, and extravagance of the internal-combustion engine. There are hunger, thirst, poverty, pain, sorrow, injustice, death ${ }^{29}$.

If on the one hand, the Escape of the Prisoner may be associated with longing and reaction, an escape back into the reality of things, the Flight of the Deserter, on the other, it is largely concerned with denial to accept the state of things, an escape out of reality. Therefore, this latter kind of escape, because it does not propel someone to action (apart from desertion in itself), it does not promote change. It seems to me that this second and not so desirable kind of escape is largely related to despair, a reaction that often precedes desertion: during times of great crisis, the ones who lose hope are often unable to see beyond the dark moments. Instead of working towards a solution, they often go into despair and flee.

In view of the arguments above, it may be argued that the Escape Tolkien believes fantasy narratives provide helps one keeping hope alive and acting even in the face of imminent defeat. Concerning the longing this kind of story awakens, in addition to being connected with a desire for change, it is also connected with what C. S. Lewis calls our desire for a far-off country, a glimpse of other-worlds: "(...) a desire for something that has never actually appeared in our experience" ${ }^{30}$. Such longing is not simply for something that does not exist, but rather for a transcendent world. Therefore, the Escape provided by fantasy narratives is also a form of wish fulfilment. Such quality is associated with the

\footnotetext{
${ }^{29}$ Ibidem, p. 65 a 66.

${ }^{30}$ C. S. Lewis, The Weigth of Glory, 2001, p. 30.
} 
last of the three items Tolkien regarded as the essential virtues of fantasy narratives: Consolation.

Towards the end of On Fairy Stories, Tolkien argues that even though Escape and Consolation are naturally closely intertwined, there is a central distinction between them. While the consolation provided by the former is largely associated with the imaginative satisfaction of ancient desires (e.g.: the desire for a glimpse of other-worlds or of conversing with other living things), the latter is deeply concerned with what the author calls "the Consolation of the Happy Ending", which he ventures to claim that all complete fantasy stories must have. For such kind of consolation, the author coins a specific name: Eucatastrophe ${ }^{31}$, the "sudden joyous turn" or the joy of the happy ending. For Tolkien, this kind of consolation, which is characterized by a sudden and miraculous grace that is bestowed upon the characters in the narrative in the face of imminent defeat, is the highest function of fantasy narratives. Eucatastrophe, however,

(...) does not deny the existence of dyscatastrophe ${ }^{32}$, of sorrow and failure: the possibility of these is necessary to the joy of deliverance; it denies (in the face of much evidence, if you will) universal final defeat and in so far is evangelium, giving a fleeting glimpse of Joy, Joy beyond the walls of the world, poignant as grief ${ }^{33}$.

In The Lord of the Rings, Tolkien's most acclaimed work, the most vivid instances of both dyscatastrophe and Eucatastrophe occur towards the end of the narrative, when Frodo and Sam finally reach the mouth of Orodruin, the volcano located in Mordor where the One Ring was forged and the only place it can be destroyed. Then Frodo, succumbing to the power and influence of the Ring, is not able to cast it into the fire:

The light sprang up again, and there on the brink of the chasm, at the very Crack of Doom, stood Frodo, black against the glare, tense, erect, but still

\footnotetext{
${ }^{31}$ Tolkien's Eucatastrophe is derived from the Greek word katastrephein, kata (down) and strephein (turn). By adding the prefix "eu-" (good), Tolkien changed the negative meaning of the original word to a positive one: the "good catastrophe".

${ }^{32}$ Also coined by Tolkien and derived from the Greek word katastrephein, it means the opposite of Eucatastrophe; it is the "bad catastrophe".

33 J. R. R. Tolkien, Tree and Leaf, 2001, p. 69.
} 
as if he had been turned to stone. 'Master!' cried Sam. Then Frodo stirred and spoke with a clear voice, indeed with a voice clearer and more powerful than Sam had ever heard him use, and it rose above the throb and turmoil of Mount Doom, ringing in the roof and walls. 'I have come,' he said. 'But I do not choose now to do what I came to do. I will not do this deed. The Ring is mine!'34.

In the excerpt above, the dycatastrophe is characterized by Frodo, the Ring bearer, being prevented from destroying the Ring by its influence. Frodo and Sam had come on foot from the Westernmost portion of Middle-earth, to the lands of Mordor, that lay in the far East, under much toil and grief in a journey that took one hundred and eighty-two days. From the moment they leave the Shire to the day they reach Mount Doom readers witness the hobbits' burdens as they journey across Middle-earth: Frodo and Sam suffer from hunger, thirst, physical and mental distress, and also from a series of injuries. Their journey is quite loathsome and weary, with little hope of success. Despite that, they face it with all their courage and resilience. When they finally reach the cracks of Mount Doom, ragged, famished and thirsty, readers are likely to feel relieved, thinking that the hobbits' mission had finally come to an end. However, at this very moment the sorrow and failure resulting from the dycatastrophe hits the readers (and also Sam), making their hearts fall, but only to make the joy of the happy ending more poignant, for soon after Frodo succumbs to the power of the Ring, Gollum struggles with him and manages to seize it. As he does so, however, he falls into the fire, taking the Ring with him, which is finally destroyed. At the brink of imminent defeat, the Eucatastrophe arises, corroborating Tolkien's assumption that the mark of a good fantasy story, of the higher or more complete kind, is that "[...] however wild its events, however fantastic or terrible the adventures, it can give to child or man that hears it, when the 'turn' comes, a catch of breath, a beat and lifting of the heart, near to (or indeed accompanied by) tears (...)"35.

\footnotetext{
${ }^{34}$ J. R. R. Tolkien, The Lord of the Rings, 2007, p. 1237.

35 J. R. R. Tolkien, Tree and Leaf, 2001, p. 69.
} 
There is only one more point regarding the consolation Tolkien believed fantasy stories provide which I would like to highlight. Such remark relates to the author's idea that all successful fantasies tend to rend the web of story and let a glimpse of the underlying truth they contain come through, whenever the Eucatastrophe arises. The joy derived from the Eucatastrophe, as the author points out, is not only a consolation for the sorrows of the primary world, but also (and maybe more importantly) a satisfaction and answer to the question "Is it true?". Such assumption, however, deserves some consideration.

In the section Fantasy of On Fairy Stories, Tolkien argues that children asking the question "Is it true?" when they are read a story, often want to know what kind of literature they are being told (e.g.: a fairy story, an anecdote, etc.), rather than asking about whether that story could have happened in the primary world or not. The author argues that even though children often have difficulties in telling fact from fiction, they are often aware that some sort of stories, such as fantasy stories, deal mostly with events that could not have happened. Thus, when a child asks "Is it true?", in this sense, they are actually trying to classify the story rather than trying to check on truthfulness of events. Towards the end of the essay, however, Tolkien proposes that the Eucatastrophe of fantasy stories somehow answers that question. Although the question is the same, there is a different sense to it: the Eucatastrophe in a fantasy narrative, as it was argued above, is the "sudden joyous turn" that grants a happy ending to the story in the face of imminent defeat. This turn, as the author proposes, provides a glimpse of the underlying truth contained in the narrative. Therefore, I believe that the satisfaction Tolkien argues the Eucatastrophe provides relates to one's wish to know whether such happy ending, such grace that denies "universal final defeat", is also possible in the primary world. As the writer proposes, "[...] in the 'eucatastrophe' we see in a brief vision that the answer [to the question 'Is it true?'] may be greater-it may be a far-off gleam or echo of evangelium in the real world"36. The word "evangelium" in this passage is of great

\footnotetext{
${ }^{36}$ Ibidem, p. 60.
} 
importance to a broader understanding of Tolkien's idea of consolation and Eucatastrophe. Such word, which is the Late Latin form of the Greek term euangélion, means good news and bears a strong relationship with Christianity, specifically with the four Gospels in the New Testament of the Bible. The word gospel in itself is a translation of the Late Latin evangelium, thus it also means good news. Interestingly enough, the four Gospels in the Bible are the books that tell the story of the life, death, and resurrection of Jesus Christ. His death, as Christians believe, wiped away all the sins human beings committed, while His Resurrection on the third day meant victory over Satan. As it is presented in the Bible, Satan had, through its cunning and malice, persuaded Adam and Eve to eat from the Tree of the knowledge of good and evil, which resulted in their being expelled from the Garden of Eden and in their mortality. The resurrection of Jesus, in this sense, signifies the joy of deliverance, since it denies death, the universal final defeat Tolkien talks about in his essay.

Tolkien, as a Roman Catholic, was well aware of the arguments above, so much so that he discusses them in On Fairy Stories:

The Gospels contain a fairy-story, or a story of a larger kind which embraces all the essence of fairy-stories. They contain many marvelspeculiarly artistic, beautiful, and moving: "mythical" in their perfect, selfcontained significance; and among the marvels is the greatest and most complete conceivable eucatastrophe. But this story has entered History and the primary world; the desire and aspiration of sub-creation has been raised to the fulfilment of Creation. The Birth of Christ is the eucatastrophe of Man's history. The Resurrection is the eucatastrophe of the story of the Incarnation. This story begins and ends in joy. It has preeminently the "inner consistency of reality." There is no tale ever told that men would rather find was true, and none which so many sceptical men have accepted as true on its own merits. For the Art of it has the supremely convincing tone of Primary Art, that is, of Creation. To reject it leads either to sadness or to wrath ${ }^{37}$.

Therefore, when the author argues that the Eucatastrophe of fantasy stories may be a gleam or echo of evangelium (good news) in the primary world, he is corroborating his own assumption that this type of narrative provides their readers with a kind of consolation, or gives readers a sense that life and all our

${ }^{37}$ Ibidem, p. 72. 
actions are meaningful. Such ideas, however, do not rule out the fact that "[t]he Christian has still to work, with mind as well as body, to suffer, hope, and die; but he may now perceive that all his bents and faculties have a purpose, which can be redeemed"38. The Consolation of fantasy stories, thus, is largely concerned with the fostering of hope, mostly in difficult times, such as the ones the author lived.

\section{Final remarks}

In On Fairy Stories, Tolkien suggests that all beings, whether they are fictional or not, are part of a larger and continuous narrative. The author believes that each being has a role to play in this narrative and, since all roles will cease to exist sooner or later, every single creature leaves the narrative when they have played their part. However, since such narrative goes on and our time in the role will eventually come to an end, it is essential that we use our time well. We can see that idea in his literary works, such as The Lord of the Rings, and it is more strikingly felt in Gandalf. The first time he does so is during an exchange with Frodo in the chapter The Shadow of the Past, when the hobbit expresses his wish that the finding of the One Ring and all its gruesome consequences had not happened during his time. Before such remark, Gandalf tells him (most correctly) that one's time to enter or leave the narrative is not theirs to decide, but that one should make sure that they do the best they can with the time they are given. Such notion is reinforced by the wizard in the chapter The Last Debate, when he is discussing what should be the next move in the war against Sauron:

[...] it is not our part to master all the tides of the world, but to do what is in us for the succour of those years wherein we are set, uprooting the evil in the fields that we know, so that those who live after may have clean earth to till. What weather they shall have is not ours to rule ${ }^{39}$.

\footnotetext{
${ }^{38}$ Ibidem, p. 73.

${ }^{39}$ J. R. R. Tolkien, The Lord of the Rings, 2007, p. 1133.
} 
As Gandalf points out, one cannot embrace all the problems of the world. However, it is of great importance that everyone do their part so that the burdens of their times are lessened and that the ones living after them may have the prospect of a better future. Such notion is central to a broader understanding of Tolkien's creative process and art. The author believed that fantasy narratives were a powerful means to help people live a more meaningful life, as these stories and their implicit messages may be seen as a way to preserve the past, shape the present, and guide the future. Given the fact that the author lived during the pre-, inter-, and post-wars periods, it is not hard to understand that he found in fantasy and fantasy writing a means to help people keep faith in a better future and understand the importance of taking action in times of great turmoil and distress.

\section{References}

ATTEBERY, Brian. Stories about Stories. New York: Oxford, 2014.

ATTEBERY, Brian. Strategies of Fantasy. Bloomington: Indiana, 1992.

CARPENTER, Humphrey. J. R. R. Tolkien: a biography. Boston: Houghton Mifflin, 2000.

CLUTE, John; GRANT, John. The Encyclopedia of Fantasy. London: Orbit, 1996.

FLIEGER, Verlyn. There would Always be a Fairy Tale: more essays on Tolkien. Ohio: Kent State University Press, 2017.

LEWIS, C. S. The Weight of Glory. New York: Harper Collins, 2001.

RUUD, Jay. Critical Companion to J. R. R. Tolkien. New York: Facts on File, 2011.

SAMMONS, Martha C. War of the Fantasy Worlds: C. S. Lewis and J. R. R.

Tolkien on art and imagination. Oxford: ABC-CLIO, 2010. 
TOLKIEN, J.R.R. The Monsters and the Critics and other Essays. London: Harper Collins, 1997.

TOLKIEN, J.R.R. The Silmarillion. (Edição de Christopher Tolkien). London, Harper Collins, 1999.

TOLKIEN, J.R.R. The Letters of J. R. R. Tolkien. (Edição de Humphrey Carpenter) Boston: Houghton Mifflin, 2000.

TOLKIEN, J.R.R. Tree and Leaf. London: Harper Collins, 2001.

TOLKIEN, J.R.R. The Annotated Hobbit. (Edição de Douglas A. Anderson) Boston: Houghton Mifflin, 2002a.

TOLKIEN, J.R.R. The Lord of the Rings. 2. ed. London: Harper Collins, 2007.

TOLKIEN, J.R.R. The Hobbit or There and Back Again. London: Harper Collins, 2014.

Referência para citação deste artigo DA ROCHA, Fabian. Approaching Fäerie: a study of J. R. R. Tolkien's on fairystories. Revista PHILIA | Filosofia, Literatura \& Arte, Porto Alegre, volume 1, número 2, p. 192 - 211, outubro de 2019. 